\title{
QUARTO DE DESPEJO, DE CAROLINA MARIA DE JESUS, E A INTERSECCIONALIDADE: UM DISCURSO EXTEMPORÂNEO?
}

Eli Gomes Castanho Fabrícia Carla Viviani

\section{Considerações iniciais}

Este texto nasce de uma indagação que nós, na condição de leitores contemporâneos de Quarto de despejo: diário de uma favelada (nas referências à obra, utilizaremos a sigla QD), fizemo-nos durante a leitura dessa obra, datada dos anos 50. Nela, Carolina Maria de Jesus - moradora da extinta favela do Canindé, a primeira de São Paulo, engolida pelo "progresso" logo nos anos 60 - registra em seu diário o sofrível cotidiano de catadora de papel. Em seu texto, ela parece catar, também, retratos daquela vida por 
meio do gênero diário: "Parece que vim ao mundo predestinada a catar. Só não cato a felicidade” (QD, p. 81).

Tal indagação, de nosso olhar e nosso lugar hodierno, nos levou a perceber que, pelas linhas de Carolina, se podia entrever um discurso que dialoga com o que hoje tem se atribuído a uma abordagem interseccional do feminismo negro. Isso porque, fica perceptível um posicionamento de enunciadora que é mulher, que é negra e que é favelada. Logo, parece haver uma intersecção entre, respectivamente, gênero, raça e classe. O que, num passar de olhos, já se evidencia no subtítulo da obra: diário (gênero de discurso) de uma favelada (mulher e pobre). A negritude, no entanto, fica em suspenso no título, mas é percebida logo nas primeiras linhas ou até mesmo pelas imagens que acompanham as edições com ilustrações e até mesmo fotos que remetem à narradora negra. Além disso, Carolina Maria de Jesus é ícone contemporâneo quando se trata de mulher negra, tendo emprestado seu nome a muitos espaços públicos marcados pela luta de acesso às práticas de letramento, sobretudo escolas, bibliotecas e entre outros espaços organizados por movimentos periféricos de resistência.

Nesse sentido, optamos por buscar perceber como esse discurso interseccional que hipotetizamos existir, como uma unidade não-tópica (MAINGUENEAU, 2015), ganha corpo no texto de Carolina Maria de Jesus. E, portanto, isso ocorrendo, poderíamos dizer que Quarto de desejo é extemporâneo, ou seja, nos anos 1950 já sinalizaria ao que se tem atribuído à interseccionalidade entre raça, classe e gênero.

Ocorre, porém, que ao nos depararmos com o corpus e ao buscarmos o reconhecimento dessa interseccionalidade, passamos a colocar em xeque aquela hipótese inicial. Portanto, este texto busca apresentar uma reflexão sobre o diário de Carolina, tendo como 
mote a seguinte pergunta norteadora: em que medida o discurso de Carolina Maria de Jesus é, aos olhos de leitores atuais marcados pelo colonialismo, um discurso extemporâneo?

Para isso, buscamos perceber como um dizer sobre a raça, o gênero e a classe social ganha corpo nas linhas do diário. Uma escrita decolonial nas proposições de Grada Kilomba, na medida em que o ato de descolonizar "não se existe como outra/o, mas como eu. Somos eu, somos sujeito, somos quem descreve, somos quem narra, somos autoras/es e autoridade da nossa própria realidade" (KILOMBA, 2019, p. 238). Os escritos de Carolina expressam uma reconfiguração das relações de poder em que muitas identidades marginalizadas podem, enfim, "tornar-se sujeito" ao definir suas realidades, estabelecer suas identidades e nomear suas histórias (bell hooks, 2019). Carolina conta sua própria história de vida e, ao fazê-la, reivindica humanidade como sujeito, narra as opressões sofridas e os silenciamentos impostos. Provoca um processo de fala sobre si que catalisa vozes de várias outras Carolinas. Uma "escrita da insurreição" de uma literatura feminina que tece a vida, o sentir, as trajetórias de "mundos possíveis", invoca uma "poesia da própria morada”.

E, a fim de darmos conta dessa empreitada, recorremos em parte aos conceitos da Análise do Discurso (doravante AD), na perspectiva de Dominique Maingueneau (2015, 2006 e 2005); e, por outra parte, aos estudos decoloniais (KILOMBA, 2019; COLLINS, 2019; GONZALEZ, 2019; DAVIS, 2016; CRENSHAW, 1991). Especialmente sobre a $\mathrm{AD}$, nos são válidas categorias como discurso literário, a fim de entender como a voz de Carolina se instaura nesse campo; unidade não-tópica, uma vez que, na condição de analistas, recortamos do corpus aquilo que nos parece enquadrar, hoje, num discurso interseccional; e de ethos, já que, ao enunciar, se mostra no dizer uma imagem de si como mulher, negra e favelada. 


\section{A inserção da escrita de Carolina no discurso literário}

Entender a escrita de Carolina como discurso literário é, por si só, um exercício que convoca à ressignificação da literatura, para além do que, tradicionalmente, se firmou via cânones literários. Ainda hoje, talvez, dizer que o que escreveu a autora negra e favelada pode soar como não literatura, principalmente em contextos que prezam pela arte literária como manutenção da língua de Camões ou, contraditoriamente, de outro negro da literatura, "mulato" para os livros didáticos, Machado de Assis.

Mas o que torna, então, o texto de Carolina Maria de Jesus discurso literário? Para isso, a concepção de Maingueneau (2006) pode nos auxiliar no processo (des)necessário de o legitimar como discurso literário. Para o teórico da $\mathrm{AD}$, os discursos se colam em instituições que se configuram como instâncias de fomento de diferentes gêneros de discurso. No caso do texto literário, seu habitat de circulação implica uma série de práticas que o acompanha como premiações, objeto de crítica literária, escolha como parte de um repertório curricular das escolas e até figurar entre obras selecionadas de exame de vestibular, por exemplo. Nesse sentido: "para produzir enunciados reconhecidos como literários, é preciso apresentar-se como escritor, definir-se com relação às representações e aos comportamentos associados a essa condição" (MAINGUENEAU, 2006, p. 89).

Para além do discurso literário como um campo discursivo, ele é, também, um discurso constituinte, uma vez que é fundador de discursos, por meio dele é que os gêneros ganham corpo e se cristalizam em práticas sociais. Desde nosso olhar contemporâneo, vemos o quanto o discurso literário vem se modificando e, mes- 
mo assim, reafirmando e ressignificando práticas de legitimação. Exemplo disso, são os textos literários produzidos na internet que, ao contrário de precisar do abono dos editores, se proliferam e viralizam nos meios digitais, quer seja pelos fóruns da web 2.0, quer seja pelo trabalho de influência dos chamados booktubers, que resenham a produção literária contemporânea.

O exemplo anterior somente ilustra como o literário resiste na ressignificância do tempo. O caso de Carolina, embora longe dos tempos da internet, é sintomático de uma nova postura sobre o que vem a ser literário. Seus textos talvez não tinham a intenção de se tornarem livros. Ela escrevia como forma de registrar e dar azo ao que via, sentia e resistia: "Aqui, todos impricam comigo. Dizem que falo muito bem. Que sei atrair homens. (...) Quando fico nervosa não gosto de discutir. Prefiro escrever. Todos os dias escrevo. Sento no quintal e escrevo." (QD, p. 22).

Em outra passagem, Carolina se nega a visitar um vizinho, ao que parece com segundas intenções e, como pretexto ou justificativa plausível diz: "É que estou escrevendo um livro, para vendê-lo. Viso com o dinheiro comprar um terreno para eu sair da favela. Não tenho tempo para ir na casa de ninguém” (QD, p. 27). Não obstante sua intencionalidade real, algo inalcançável por qualquer analista do discurso, temos aqui hipóteses sobre como a enunciadora se relacionava com esse universo literário. Ao que sabemos, mais tarde, ela foi "descoberta" pelo jornalista Adáulio Dantas que, como editor, fez a ponte entre a favela e o mercado editorial, especialmente com a publicação de Quarto de despejo, em agosto de 1960, de modo a instaurar o gênero diário no rol das práticas do discurso literário.

Interessante o modo como Meihy (1998, p. 87) se refere à obra: “o diário de Carolina, editado por Audálio Dantas...”. Parece ha- 
ver uma certa co-autoria do editor, ao suprimir trechos do diário, como se vê nas tantas reticências entre aspas que aparecem nas edições publicadas. Ainda assim, o trabalho do jornalista deu uma reviravolta no mercado editorial, exatamente por dar voz aos marginalizados na literatura: "pouco ou nada existia que revelasse a intimidade dos marginalizados. Tudo o que existia era ficção, escrita sobre os desprovidos e nunca por eles (MEIHY, 1998, 87).”

Ademais, a obra de Carolina inova ao trazer para o livro as marcas de um português oral, carregado do que a gramática prescritiva aponta como erro. Por seu turno, hoje, Conceição Evaristo, chama de escrevivência, essa escrita com lastro da oralidade e sua pujança, que é marca dos ancestrais, que ganham vida na pena das mulheres negras. Aliás, para definir a escrevivência a autora faz uso da imagem de uma mãe preta que cuida dos futuros senhores brancos e somente tem a voz para niná-los e para obedecer aos senhores. $\mathrm{O}$ acesso às práticas letradas, no entanto, conquistada muito mais tardiamente, como o fez Carolina quando estudou até a segunda série primária, permitiria à mulher negra ter voz e, com isso, registrar suas escrevivências:

E se ontem nem a voz pertencia às mulheres escravizadas, hoje a letra, a escrita, nos pertencem também. Pertencem, pois nos apropriamos desses signos gráficos, do valor da escrita, sem esquecer a pujança da oralidade de nossas e de nossos ancestrais. Potência de voz, de criação, de engenhosidade que a casa-grande soube escravizar para o deleite de seus filhos. E se a voz de nossas ancestrais tinha rumos e funções demarcadas pela casa-grande, a nossa escrita não. Por isso, afirmo: 'a nossa escrevivência não é para adormecer os da casa-grande, e sim acordá-los de seus sonos injustos'. (EVARISTO, 2020, p. 30) 
É emblemático, pois, em Carolina Maria de Jesus, traços da escrevivência de Conceição Evaristo (2020). A força de seus escritos igualmente acorda a casa-grande dos sonos injustos, ao denunciar a pobreza ali "escrevivida" e a condição de abandono por políticas públicas: "O Brasil precisa ser governado por alguém que já passou fome. A fome também é professora. Quem passa fome aprende a pensar no próximo, e nas crianças." (QD, p. 29).

Inocente, porém, seria dizer que ao se apropriar do código escrito teria já, a mulher negra, voz. Como visto, ainda que en passant por aqui, Carolina precisou se sujeitar às regras do mercado editorial para se fazer ouvida, mediada pela figura do jornalista, editor de seu diário. Há ritos institucionais, das editoras, que permitiram a conversão de um diário intimista em obra literária. Nesse processo de legitimação, fica latente um gosto pelo exotismo que, pela leitura, permite o acesso a um universo marginalizado visto pelo olhar do próprio marginalizado. Fica entreposto uma certa espetacularização da pobreza que, segundo Meihy (1998, p. 88) somente teria razão por conta do "momento político e cultural do florescimento da democracia e da contracultura. A democracia e a contracultura implicavam, em conjunto, a definição das minorias e com elas a expressão política dos grupos envolvidos."

Foi nessa brecha da história entre as políticas desenvolvimentistas dos anos 1950 e o golpe militar de 64 que floresce o texto de Carolina. Nesse contexto, a aceitação é grande, com esgotamento imediato das primeiras tiragens (trinta mil, segundo MEIHY (1998); dez mil, segundo SILVA (2008)), tradução para outros idiomas, inclusive até superando Jorge Amado.

Talvez o sucesso editorial e o próprio achamento da escritora residam no ideário de exotismo em torno de Carolina, que leva o 
leitor a se perguntar: como uma mulher, negra e favelada poderia vir a se tornar escritora? Nessa lógica, seu sucesso estaria condicionado a seu estado de exotismo, como algo diferente no mundo dos brancos. Ainda que se tenha a marcação de um espaço no mercado literário, é sempre um espaço concedido pelo branco, o editor e jornalista que a descobre. Com isso, coloca-se em cena uma volta ao colonialismo, por meio de práticas de exaltação do exótico:

Experiencia-se o presente como se estivesse no passado. Por um lado, cenas coloniais (o passado) são reencenadas através do racismo cotidiano (o presente), e por outro lado o racismo cotidiano (o presente) remonta cenas do colonialismo (o passado). A ferida do presente ainda é ferida do passado e vice-versa; o passado e o presente entrelaçam-se como resultado. (KILOMBA, 2019, p. 158)

Trata-se de um espaço que é dado e facilmente tirado pelos senhores, que fazem a cessão. $\mathrm{O}$ caso de Carolina é sintomático disso. A escritora - após o sucesso com seu best-seller, que a tirou da pobreza e a colocou em casa de alvenaria - vai, aos poucos, sendo esquecida.

Hoje parece haver um resgate de sua obra e de sua história, como forma de romper um silenciamento imposto a autoras mulheres e, principalmente, negras. No entanto, na década de 80 , quando Vogt (1983 p. 206) escreveu sua crítica para a coletânea "Os pobres na literatura", o esquecimento de Quarto de Despejo e de sua autora já eram uma tônica. A ascensão e descenso da escritora é comparada pelo estudioso aos negros do Cafundó, comuni- 
dade quilombola de Salto de Pirapora, interior de São Paulo que, também, quando evidenciados pela academia e mídia "em virtude do vocabulário africano conservado ativamente em sua comunidade, passaram a ter sérias dificuldades para encontrar trabalho como diaristas, sob a alegação dos patrões de que artistas não precisam trabalhar".

Os casos anteriores ilustram o exotismo que problematiza $\mathrm{Ki}$ lomba. Carolina vive o fim de seus dias, num sítio em Parelheiros, quase tudo o que sobrou dos tempos áureos da publicação de sua obra. Enfrentou dificuldades e voltou à vida de catadora, tendo enfrentado problemas nas negociações, dado sua passagem pela fama; afinal, o que uma escritora estaria fazendo ali, catando papel? Novamente pobre, morreu, esquecida, em 1977.

\section{A interseccionalidade como unidade não tópica}

Conforme já mencionado, ao lermos Carolina Maria de Jesus, um insight nos ocorreu e nos motivou à escrita deste texto. Ela, do quarto de despejo que é a favela, (d)enuncia em seu diário os percalços de ser mulher, negra e favelada, no recorte temporal dos anos 50. Estaria, ali, portanto, muito à frente de seu tempo, problematizando a condição de mulher atravessada pelas categorias de raça e classe social.

Articular gênero com raça e classe, numa visão interseccional, implica necessariamente aproximações com as feministas negras, uma vez que o conceito integra o território discursivo desse grupo. Para Carla Akotirene (2019, p. 19), é preciso reconhecê-lo como instrumento teórico-metodológico que indissocia racismo, capitalismo e cisheteropatriacarlismo, produzindo "avenidas identitárias 
em que mulheres negras são repetidas vezes atingidas pelo cruzamento e sobreposição de gênero, raça e classe, modernos aparatos coloniais".

O Coletivo Combahee River (CRR), movimento de mulheres negras e lésbicas do anos 70, publica um Manifesto seminal em 1977. Nele, considera o feminismo negro como resultado de um processo histórico de resistência e que está vinculado ao processo mais amplo de movimento de libertação dos negros nos 1960 e 1970. Ao considerar que os sistemas de opressão são interligados e inseparáveis, há uma denúncia do racismo praticado pelo feminismo das mulheres brancas e do sexismo dos homens negros e brancos. A atuação do movimento das mulheres negras se fundamenta numa política antirracista e antissexista e, posteriormente, aproxima-se de outras demandas como heterossexismo e da opressão econômica sob o capitalismo. Afinal, a situação de classe tem raça e sexo, em que "as opressões racial e sexual são determinantes significativos para suas vidas laborais e econômicas" (COMBAHEE RIVER, 2019, p. 201).

As nuances desse sistema interseccional de opressões como mecanismo de controle e dominação foram abordadas por várias pensadoras, como Angela Davis (2016), Patrícia Hill Collins (2019) e bell hooks (2019). No Brasil, a articulação entre as desigualdades de raça e gênero já estava presente em trabalhos de feministas negras no contexto da redemocratização dos anos 80. Em 1984, Lélia Gonzalez escreve trabalho seminal acerca das formas de opressão articuladas ao processo colonial, que de maneira persistentes e duradouras, naturalizam as hierarquias sociais. Em " $\mathrm{Ra}$ cismo e sexismo na cultura brasileira", a pensadora problematiza o mito da democracia racial e considera que o "racismo se constitui como a sintomática que caracteriza a neurose cultural brasileira" (GONZALEZ, 2019, p.238, grifos da autora) que, combinado com 
sexismo, produz efeitos violentos sobre a mulher negra, representada na "mulata e doméstica são atribuições de um mesmo sujeito" (p. 242).

Ao trazermos à baila as relações entre QD e as categorias de classe, gênero e raça, hipotetizamos a existência de um discurso interseccional, entendido como uma unidade não tópica. Nesse sentido, seria uma categoria que nós, analistas, passamos a observar e que não tem relação alguma com instituições onde esses discursos são produzidos. Respectivamente, esses discursos não institucionalizados seriam unidades não tópicas, enquanto que os outros, ligados a instituições, seriam unidades tópicas, conforme explica Maingueneau (2015, p. 66):

Uma distinção se impõe naturalmente entre os dois tipos: as unidades que chamamos tópicas (Maingueneau, 2003, 2005), de alguma forma dadas, pré-recortadas pelas práticas sociais, e as que chamaremos não tópicas, construídas pelos pesquisadores.

Nossa reflexão ao que se tem chamado de interseccionalidade como unidade não tópica - dado o pertencimento ao que podemos chamar de um discurso interseccional - nos levou a problematizar ainda mais as discussões em torno desses atravessamentos.

Sobretudo com Haider (2019) que faz duras críticas ao que chama de política identitária. Esse estudioso, radicado nos Estados Unidos e de origem paquistanesa, apresenta uma profícua discussão a partir de sua condição de imigrante, principalmente após os ataques de 11 de setembro e os consequentes ataques que ele, na condição de estrangeiro com traços árabes, passou a sofrer em solo estadunidense. 
Haider recupera a importância do referido Manifesto do Coletivo Combahee River que, ao criticar posturas racistas e sexistas no projeto do socialismo revolucionário, começa a colocar em pauta a condição de outros setores excluídos. Muito embora o grupo seja composto por mulheres negras e lésbicas, outras pautas ligadas a outras identidades não ficaram de fora, tendo muitas das integrantes apoiado movimentos dos trabalhadores da construção civil. Acreditavam, como aponta uma militante, Demita Fraizer, citada no livro de Haider (2019, p.33): "Entendíamos que a construção de alianças era crucial para a nossa própria sobrevivência”.

Se, por um lado, o projeto do CCR era questionado pela esquerda por considerar uma política identitária; por outro, ele passou a ser bandeira, também, daqueles cujos princípios eram diametralmente opostos aos ideais do CCR. Em razão disso, Haider exemplifica com polêmicas em torno de Hilary Clinton e seu oponente, Bernie Sanders, nas prévias para as eleições em que Trump venceu os democratas, em 2016. Sob a égide da interseccionalidade, Hilary ataca Sanders por haver sido negligente com os negros americanos. Por outro lado, como argumentado por Haider em citação a analistas políticos, o liberalismo dos Clinton, quando esses estiveram no poder, fizeram "mais mal às comunidades negras do Reagan fez", em referência a um ícone do conservadorismo americano.

Tal discussão relembra Hall (2005) e o caso do juiz negro, Clarence Thomas, nomeado para a suprema corte por Bush para apaziguar as tensões entre democratas e conservadores. A questão, no entanto, ganha outros contornos ao vir à tona um caso de assédio sexual envolvendo o juiz e uma mulher negra. A dinâmica passou a polarizar opiniões pelo crivo da identidade de gênero e de raça entre homens e mulheres, brancos ou negros. Por esse exemplo, Hall ilustra como existe um jogo em torno das identidades e que 
políticos, da esquerda e da direita, beneficiam-se de uma política identitária. Assim, as políticas em torno da identidade cultural, no discurso político, jogam com os co-enunciadores para garantir a adesão desses a seu projeto de dizer.

De modo semelhante, pode-se dizer sobre a construção de um discurso intersecional que, na contemporaneidade, parece estar cada vez mais generalizado, aproximando-se do desgaste que tem o termo "empoderamento", já tão apropriado pelo discurso publicitário, pelos programas matinais de televisão aberta. Ao atentar para a tessitura multifacetada da vida das mulheres negras, a luta interseccional é uma luta antirracista, antissexista e anticapitalista. Utilizar o conceito esvaziado de sua crítica radical ao capitalismo e suas formas de opressão acaba por recair no uso indiscriminado do conceito e na reprodução do ideal burguês, recaindo na "armadilha" que denuncia Haider. Tal armadilha não estaria em considerar a identidade na análise social, mas "analisá-la como se fosse algo exterior às determinações materiais da vida social”. Assim, é necessário "assumir que as identidades, inclusive a raça, são socialmente construídas [...] Em um sentido mais revolucionário, a afirmação da raça é feita apenas para que um dia seja possível superá-la” (ALMEIDA, 2019, p. 19).

Nesse sentido, parece haver, pois, uma banalização do termo interseccional, com vistas, possivelmente, a invisibilizar questões mais urgentes ligadas à manutenção das estruturas de poder e de opressão, ao reforçar o que se pretende criticar. Longe de solucionar esse imbróglio, o que se propõe aqui é apenas sinalizar que Carolina traz a urgência de desvelar o sistema de opressão sobre mulheres pobres, negras e faveladas e pensar como os silenciamentos e as opressões são vividos de maneira inteiriça em vários aspectos de suas vidas (DEVULSKY, 2021). 


\section{Carolina em busca do arco-íris: diário de uma mulher negra e favelada}

Tentamos, na análise que segue, dar um trato fragmentado às categorias da tríade interseccional, com vistas a facilitar o trabalho metodologicamente. No decorrer da análise, porém, vimos que quando se vê o sujeito de forma inteiriça, tal projeto de fragmentação torna-se inviável. Portanto, a partir de recortes selecionados, procuramos perceber como uma imagem de si - um ethos - ganha corpo nas linhas de Carolina, mulher, negra e favelada.

Recorte 1

... Quando eu era menina o meu sonho era ser homem para defender o Brasil porque eu lia a Historia do Brasil e ficava sabendo que existia guerra. Só lia os nomes masculinos como defensor da patria. Então eu dizia para a minha mãe:

- Porque a senhora não faz eu virar homem?

Ela dizia:

- Se você passar por debaixo do arco-iris você vira homem.

Quando o arco-iris surgia eu ia correndo na sua direção. Mas o arco-iris estava sempre distanciando. Igual os politicos distante do povo. Eu cançava e sentava. Depois começava a chorar. Mas o povo não deve cançar. Não deve 
chorar. Deve lutar para melhorar o Brasil para os nossos filhos não sofrer o que estamos sofrendo. Eu voltava $e$ dizia para a mamãe:

- O arco-iris foge de mim.

... Nós somos pobres, viemos para as margens do rio. As margens do rio são os lugares do lixo e dos marginais. Gente da favela é considerado marginais. Não mais se vê os corvos voando as margens do rio, perto dos lixos. Os homens desempregados substituíram os corvos. (QD, p. 53 e 54, grifos nossos)

No recorte 1, os atravessamentos a partir do gênero e da classe ficam mais evidentes. A enunciadora o faz pela criação de uma cenografia, alinhavada pelos fios da memória, de modo a demonstrar como certos saberes instituídos são ativados e, motivada pela condição de superar a miséria, tentam ser desestabilizados. Nesse movimento, intertextos são presentificados no interdiscurso.

Em primeiro lugar, temos a enunciação sobre o desejo de ser homem, seguido de uma justificativa pautada nas práticas discursivas, letradas, da enunciadora: o fato de ler/ver somente personagens homens nos livros de história. Fica sugerido não o desejo de ser homem, não uma insatisfação com sua identidade de gênero; ao contrário: o desejo de ser o sujeito da transformação social "para defender o Brasil". Mas, para isso, haveria de ter nascido homem. Isso porque seu imaginário infantil, advindo dos livros de história, sinaliza apenas para os homens como aqueles que podem se revestir de heroísmo nacional: Só lia os nomes masculinos como defensor da patria. 
Ao se questionar sobre esse ponto de vista, Carolina questiona o instituído: o fato de homens tão somente ocuparem cargos públicos e, por conseguinte, tirarem o Brasil da miséria. Ela adianta uma discussão recente sobre a representatividade feminina no campo político. Esse posicionamento surpreende leitores contemporâneos ao se perguntar sobre a competência discursiva, conforme Maingueneau (2005), uma vez que a enunciadora, distante das políticas públicas de escolarização, estudou até a segunda série primária, permitindo-se dizer o que diz.

Carolina nos provoca ao escancarar nossa cegueira em relação aos "muitos mundos" e sinaliza um deslocamento para outros modos de ver o mundo e produzir conhecimento. Conforme aponta Patrícia Collins (2019, p. 414), “o poder da experiência” conjuga subjetividade e objetividade e proporciona às mulheres vivenciar modos diferentes de saber, "uma localizada no corpo e no espaço que ela ocupa, e outra que transcende esse espaço". São formas de conhecimento que permitem um saber que reside nas próprias mulheres e são vivenciadas diretamente no mundo. Subverte a lógica de validação de conhecimento que expressam relações de poder que apontam hegemonicamente a educação formal como caminho para o pensamento e determina quem fala. Por isso, é fundamental distinguir conhecimento de sabedoria, elemento já perceptível nos escritos de Carolina. Invocando as experiências vividas de mulheres negras como critério de credibilidade, Collins (2019, p. 411) nos explica que "conhecimento sem sabedoria é suficiente para os poderosos, mas sabedoria é essencial para a sobrevivência dos subordinados".

A recorrência à mãe nos remete ao saber popular em torno do arco-íris. O mito de que ao final há um pote de ouro é substituído pela transmutação do feminino para o masculino. Possivelmente, dada a exclusão que vive a mulher, não deixaria de ser um novo 
acesso, uma versão ressignificada do pote de ouro. O fantasioso perde forças ante a violência do real, correr atrás do arco-íris "cança”. A falta de retorno que o mito oferece, a faz voltar à realidade. Com isso, a cenografia instaurada pelas memórias da infância recai sobre a miserável realidade, reforçada pela fala da mãe, que a conscientiza sobre a condição de pobreza que vivem: "nós somos pobres, viemos para as margens do rio."

Há, implicitamente, um jogo em torno da palavra margem: estar à margem do rio, no sentido literal que isso representa, a favela do Canindé à margem do rio Tietê; e estar à margem da sociedade, dos direitos básicos de cidadão. Além disso, a perífrase “à margem" soa como o equivalente a "marginal", "marginalizado", cuja conotação remete ao desprovido.

A metáfora atravessa toda a obra e, nesse recorte 1 , temos amostras significativas. De modo geral, a pobreza já é bem marcada pelo título do livro, que também é metafórico. O que vem a ser o quarto de despejo? É a favela em si. Em outros momentos, Carolina apresenta São Paulo numa alegoria a uma grande casa:

\section{Recorte 2}

Eu classifico São Paulo assim: O Palacio, é a sala de visita. A prefeitura é a sala de jantar e a cidade é o jardim. E a favela é o quintal onde jogam os lixos. (QD, p.32, grifos nossos)

Novamente, mais adiante, a metáfora da favela como o mais indesejado lugar de uma casa, é retomado. Ali, juntamente com o termo marginais que, implicitamente, a mãe de Carolina retoma no recorte 1 . 


\section{Recorte 3}

Revoltei contra o tal Serviço Social que diz ter sido criado para reajustar os desajustados, mas não toma conhecimento da existência infausta dos marginais. Vendi os ferros no Zinho e voltei para o quintal de São Paulo, a favela. ( $Q D, p .40$, grifos nossos)

Numa progressão de sentidos depreciativos sobre a favela, a metáfora segue, desta vez com alusão ao campo da saúde:

\section{Recorte 4}

Quando eu vou na cidade tenho a impressão que estou no paraizo. Acho sublime ver aquelas mulheres e crianças tão bem vestidas. Tão diferentes da favela. As casas com seus vasos de flores e cores variadas. Aquelas paisagens há de encantar os olhos dos visitantes de São Paulo, que ignoram que a cidade mais afamada da América do Sul está enferma. Com suas úlceras. As favelas. (QD, p. 85, grifos nossos)

Trata-se de uma tônica constante na obra de Carolina a recorrência à favela como o resto, o desprezível, inclusive na fala da mãe, no recorte 1, isso fica evidente: "Não mais se vê os corvos voando as margens do rio, perto dos lixos. Os homens desempregados substituíram os corvos." Por esse viés metafórico, todo o diário se reveste de uma cenografia que marca o lugar de onde se fala: o quarto de despejo, o quintal, as úlceras da cidade doente... Somado a isso, é 
perceptível no discurso de Carolina certa culpabilização da condição aos políticos, que nada fazem para reverter o quadro de desigualdade social instalado. Daí o desejo de tornar-se homem, para subverter a pobreza que assola o Brasil, as chagas de uma cidade doente, invisíveis aos homens que estão no poder.

Apesar de tudo, há necessidade de resistir para sobreviver. A cenografia criada em torno das memórias sobre correr atrás do arco-íris é outra metáfora para a busca incansável pela melhoria. Aos leitores contemporâneos, pode-se estabelecer um intertexto com a busca pela utopia, tão defendida pelo discurso progressista pela pena de Eduardo Galeano (2001, p.230):

Ella está en el horizonte - dice Fernando Birri-. Me acerco dos pasos, ella se aleja dos pasos. Camino diez pasos y el horizonte se corre diez pasos más allá. Por mucho que yo camine, nunca la alcanzaré. ¿Para qué sirve la utopía? Para eso sirve: para caminar.

O movimento de Carolina é sempre o de correr atrás desse arco-iris, insistir na utopia de sair da favela. Para isso, conta com a leitura e a escrita como armas, inclusive para contestar o racismo cotidiano. Como se vê no recorte 5 :

Recorte 5

... Eu escrevia peças e apresentava aos diretores de circos.

Eles respondia-me: 
- É pena você ser preta.

Esquecendo eles que eu adoro a minha pele negra, e o meu cabelo rustico. Eu até acho o cabelo de negro mais iducado do que o cabelo de branco. Porque o cabelo de preto onde põe, fica. É obediente. E o cabelo de branco, é só dar um movimento na cabeça ele já sai do lugar. É indisciplinado. Se é que existe reincarnações, eu quero voltar sempre preta. (...)

O branco é que diz que é superior. Mas que superioridade apresenta o branco? Se o negro bebe pinga, o branco bebe. A enfermidade que atinge o preto, atinge o branco. Se o branco sente fome, o negro também. A natureza não seleciona ninguém. (QD, p. 64, 65, grifos nossos)

O trecho acima é um dos mais significativos sobre a negritude em Carolina Maria de Jesus. Após narrar um episódio de racismo escancarado, percebemos um posicionamento de autoafirmacao da negritude. Fica latente um ethos discursivo de uma mulher consciente do racismo e, ao mesmo tempo, que se orgulha, a ponto de, numa alusão ao espiritismo, querer se reencarnar preta novamente.

A referência ao cabelo do negro, razão de muito orgulho dos tempos atuais, inclusive em comercais de xampu e em recentes politicas identitárias, já estava lá nos anos 50 de Carolina. E, para encerrar seu argumento, a enunciadora marca o humano como ponto em comum entre brancos e negros, uma vez que todos estão vulneráveis: "A natureza não seleciona ninguém". 
Carolina, assim como Grada Kilomba, reivindica a humanidade numa realidade que desumanização o sujeito negro, colonizando-o novamente. "Não desejo ser super-humana mais do que desejo, não ser subumana (...) Quando estou com raiva, quero ter a liberdade de ficar com raiva, e quando estou fraca, gostaria de ter a liberdade de ser fraca"'. Sentir-se livre para permitir a existência em toda sua complexidade: "zangada, quieta, forte, fraca, alegre, triste; como sabendo as respostas, como não as sabendo de todo" (KILOMBA, 2019, p. 234 e 235).

Outro ponto que chama atenção nos escritos é a observação e problematização da diferença, do ser negro e de sua relação com a pobreza:

\section{Recorte 6}

"Saí a noite, e fui catar papel. Quando eu passava perto do campo do São Paulo, varias pessoas saiam do campo. Todas brancas, só um preto." ( $Q D, p .14)$

É visível um incômodo de Carolina sobre lugares não ocupados por negros, sobretudo na esfera do lazer. Ao negro, como ela, cabe catar papel para sobreviver.

Em outro trecho, podemos apreender um imaginário da negritude pela diferenciação com o branco, sendo que a este último se vê uma certa ganância, que não é comum aos pretos. Carolina demonstra esse posicionamento ao narrar uma corrida de mulheres na favela, em que Vilma, a filha de Florenciana, havia perdido a competição e estava inconformada pela falta de premiação à filha. 


\section{Recorte 7}

"A Florenciana é preta. Mas é tão diferente dos pretos por ser muito ambiciosa. Tudo que ela faz é visando o lucro. Creio que se ela fosse dona de um matadouro havia de comer os chifres e os cascos do boi" (QD, p. 75 e 76)

Ao sugerir certa representação do negro como esse sujeito despretensioso de aspirações capitalistas, a enunciadora, com esse exemplo do recorte 7, diz aos leitores: "sou isso aqui e não aquilo lá” (BARTHES apud MAINGUENEAU, 2008, p.13).

Romper com a pobreza instalada é a eterna corrida atrás do arco-íris de Carolina. A condição de mulher, negra e pobre perpassa e é constituinte da própria existência da escritora. Esse correr atrás do arco-íris é metafórico de estratégias empregadas por Carolina para superar a miséria e uma delas bastante evidente são as práticas de leitura e escrita, que implicam, consequentemente, uma leitura do mundo. Em certa parte do diário, ela relata que é criticada por outros favelados por não gostar de beber, a resposta a essa crítica gera a seguinte reflexão: "Eu prefiro empregar o meu dinheiro em livros do que com álcool.” (QD, 74)

É bastante frequente essa recorrência às práticas letradas como refúgio contra os dissabores da dura vida na favela: "Não saí porque está chovendo. (...) Passei o dia escrevendo" (QD, 121). Nesse sentido, é perceptível uma imagem de mulher que prioriza os estudos, a leitura, a escrita, muito embora o acesso a materiais seja bastante escasso: "Saí de casa as 8 horas. Parei na banca de jornais para ler as notícias principais" (QD, 107). Fica evidente um interesse da enunciadora sobre os rumos políticos do país, o que interferem diretamente na precariedade de sua condição de vida. No sentido do 
poema de Brecht, Carolina, semianalfabeta como hoje é relembrada em algum meio, não é, em hipótese alguma, analfabeta política:

\section{Recorte 8}

"Ontem li aquela fábula da rã e da vaca. Tenho a impressão que sou a rã. Queria crescer até ficar do tamanho da vaca. (...)

Que lê que o Dr. Adhemar disse nos jornais que foi com dor no coração que assinou o aumento, diz:

- O Adhemar está enganado. Ele não tem coração.

- Se o custo de vida continuar subindo até 1960 vamos ter revolução.” (QD, 130)

Vemos, pelo recorte 8 , um pouco do repertório variado de leitura de Carolina: de fábulas a notícias do jornal impresso. O modo como se relaciona com as práticas de leitura e escrita nos dá elementos para aprender o quanto era uma pessoa letrada, no sentido de estado de quem se apropria das práticas de leitura e escrita, conforme defende Soares (2003). Ou então como sugere Meihy (1998, p. 91), Carolina "sabia, que, por saber ler e escrever, tinha domínio dos códigos dos poderosos”.

Parece haver certa diferenciação que a enunciadora faz em relação aos sujeitos que sabem e que não sabem ler e escrever. Quando apresenta alguns personagens, sempre acaba trazendo essa informação, o que soa até mesmo como certa falta de paralelismo, 
como nos seguintes exemplos, de apresentação dos personagens: Zefa: "É mulata. É bonita. É uma pena que sabe ler" (QD, 109); Ditinho: “... é um veterano da favela. Mas é um pelado. Não aprendeu ler. Não aprendeu um oficio. Só aprendeu beber pinga." (QD, 110); prostitutas: "Elas não sabiam ler. Nem cuidar de uma casa. A unica coisa que elas conhecem minuciosamente e pode lecionar e dar diplomas é a pornografia." (QD, 89).

Ler e escrever ficam sugeridos como algo diferenciador e que a afastaria do vício pelo álcool e da prostituição, além de que permitiria mais atenção e o cuidado com os filhos. Em outro trecho, ela faz um jogo de palavras - bastante sofisticado por sinal - sobre a ausência de outras mães com seus filhos, em detrimento da disponibilidade para relacionar-se com outras pessoas: "Pretere os filhos e prefere os homens" (QD, 49). Em trecho anterior, Carolina lamenta a saudade da mãe e sinaliza para ações que levaram-na à valorização das práticas letradas:

\section{Recorte 9}

"Queria [a mãe] que eu estudasse para professora. Foi as contigências da vida que lhe impossibilitaram concretizar seu sonho. Mas ela formou o meu carater, ensinando-me a gostar dos humildes e dos fracos. É porisso que eu tenho dó dos favelados. Se bem que aqui tem pessoas dignas de despreso, pessoas de espirito perverso." $(Q D, 49)$

Está em jogo uma formação que vai além das práticas de leitura e escrita, que diz respeito à alteridade, à formação de uma consciência de classe, inclusive para perceber "as contingências da 
vida" que impediram a realização do sonho da mãe. Portanto, evidencia-se um fortalecimento ideológico advindo das práticas de letramento, ligadas à leitura do entorno e à capacidade de "tornar-se sujeito", conforme sugerido por bell hooks (2019, p. 56):

processo que só se inicia quando o indivíduo busca compreender como as estruturas de dominação atuam em sua própria vida, à medida que desenvolve consciência e pensamento críticos, inventando novas formas de existir e resistir distintas do espaço marginal da diferença internamente definida.

Esta é a condição para se caminhar em direção a uma transformação radical da identidade negra, ou seja, a construção da "subjetividade radical negra que seja vista e não vigiada pelo Outro dominante que afirma nos conhecer melhor do que nós mesmos" (bell hooks 2019, p. 68, grifo da autora).

\section{Considerações finais}

Em QD, Maria Carolina de Jesus evidencia o poder da experiência como elemento de conhecimento para a análise de estruturas de poder que entrelaçam raça, gênero e classe. Seus escritos se aproximam das proposições de Patrícia Collins (2019) que, ao desnudar a "experiência vivida como critério de significado e credibilidade", são inseridas no fenômeno social mais amplo. Tal processo vivenciado dá luz ao texto literário de Carolina, indo ao encontro das escrevivências de Conceição Evaristo, fazendo acordar a Casa-Grande de seu sono. Rompe com a máscara do silenciamento, processo utilizado para manter e legitimar estruturas sociais 
de exclusão racial (KILOMBA, 2019). Uma máscara que protege o ser branco ao controlar quem fala e o que se fala. Com isso, a escravidão, o colonialismo, o racismo, o sexismo ficam relegados ao segredo. Carolina, mesmo tendo como maior algoz a crítica literária (MEIHY, 1998), ocupa espaço na produção de conhecimento e insurge contra a desumanização do povo negro, pobre e favelado.

Em nosso percurso de análise, pressupomos a necessidade metodológica de identificar separadamente recortes ligados às três categorias da interseccionalidade. Porém, durante a análise ficou evidente que tais categorias não se separam, as opressões de gênero, raça e classe são constitutivas do discurso de Carolina. Por essa experiência, adiantamos a resposta à pergunta-título deste texto: a presença de um discurso interseccional - como unidade não tópica - é extemporâneo aos olhos dos leitores contemporâneos, marcados por um posicionamento acerca da identidade. Por outro lado, as opressões sofridas por tantas Carolinas já estavam expostas, sangrando em carne viva, antes mesmo dos anos 50. Nosso olhar hodierno e colonizado é que eclipsou as mazelas sofridas desde a chegada do primeiro navio negreiro ao Brasil.

Portanto, Carolina tece em seu texto as opressões cotidianas de raça, gênero e classe que são experienciadas de forma inteiriça num emaranhado que produz um sentido de inconformidade com as opressões sofridas. Seu discurso é permeado por sentidos que traduzem resistência: à fome, ao racismo, à condição de mulher preta e pobre, à miséria... Resistência que vem pela voz, que representam tantas outras. (Re)existe e se reinventa pela escrita, pela escrita preta. 


\section{Referências}

AKOTIRENE, C. Interseccionalidade. São Paulo: Sueli Carneiro; Pólen, 2019.(Col. Feminismos Plurais).

ALMEIDA, S. L. Prefácio à edição brasileira de 'Armadilhas da Identidade: Raça e Classe nos dias de hoje’. São Paulo: Veneta, 2019.

COMBAHEE RIVER, C. Manifesto do Coletivo Combahee River. Tradução: PEREIRA, S; GOMES, L. Plural - Revista de Ciências Sociais, v. 26, n. 1, p. 197-207, 10 jul. 2019.

COLLINS, P. H. Pensamento feminista negro: conhecimento, consciência e política de empoderamento. São Paulo: Boitempo, 2019.

CRENSHAW, K. Mapping the Margins: Intersectionality, Identity Politics, and Violence Against Women of Color. Stanford Law Review. 43(6), p. 1241-99, 1991.

DAVIS, A. Mulheres, raça e classe. São Paulo: Boitempo, 2016.

DEVULSKY, A. Colorismo. São Paulo: Jandaíra, 2021. (Col. Feminismos Plurais).

EVARISTO, C. A escrevivência e seus subtextos. In: DUARTE, C. L; NUNES, I. R. (Org.). Escrevivência: a escrita de nós : reflexões sobre a obra de Conceição Evaristo. Rio de Janeiro: Mina Comunicação e Arte, 2020.

GALEANO, E. Las palabras andantes. $5^{\text {a }}$. ed. Buenos Aires: Catálogo SRL, 2001.

GONZALEZ, L. Racismo e sexismo na cultura brasileira. In: HOLLANDA, H. B. de. (org.) Pensamento feminista brasileiro: formação e contexto. Rio de Janeiro: Bazar do Tempo, 2019.

HAIDER, A. Armadilha da identidade: raça e classe nos dias de hoje. Trad. Leo Vinícius Liberato. São Paulo: Veneta,2019. (Coleção Baderna).

HALL, S. A identidade cultural na pós-modernidade. Rio de Janeiro: DP\&A, 2005.

hooks, b. Anseios. Raça, gênero e políticas culturais. São Paulo: Elefante, 2019.

JESUS, M.C. Quarto de despejo. Diário de uma favelada. 10 ed. São Paulo: 
Ática, 2014.

KILOMBA, G. Memórias da plantação: episódios de racismo cotidiano. Tradução de Jess Oliveira. Rio de Janeiro: Editora Cobogó, 2019.

MAINGUENEAU, D. Discurso e análise do discurso. Trad. Sírio Possenti. São Paulo: Parábola, 2015.

MAINGUENEAU, D. A propósito do ethos. Tradução de Luciana Salgado. In: MOTTA, A. R.; SALGADO, L. (Org.). Ethos discursivo. São Paulo: Contexto, 2008.

MAINGUENEAU, D. Discurso literário. Trad. Adail Sobral. São Paulo: Contexto, 2006.

MAINGUENEAU, D. Gênese do discurso. Trad. Sírio Possenti. Curitiba: Criar, 2005.

MEIHY, J. C. S. B. Carolina Maria de Jesus: emblema do silêncio. Revista USP, São Paulo, n. 37, p. 82-91, 1998.

SILVA, J. C. G. da. Carolina Maria de Jesus e os discursos da negritude: literatura afro-brasileira, jornais negros e vozes marginalizadas. História \& Perspectivas, Uberlândia, n. 39, p. 59-88, jul.dez.2008

SOARES, M. Letramento: um tema em três gêneros. Belo Horizonte: Autêntica, 2003.

VOGT, C. Trabalho, pobreza e trabalho intelectual (O quarto de despejo, de Carolina Maria de Jesus). In: SCHWARZ, R. Os pobres na literatura brasileira. São Paulo: Brasiliense, 1983. p. 204-213. 